\title{
Research on Professional Quality Training and Occupation Adaptability of Higher Vocational Students Majoring in Economic Management
}

\author{
Lingling Wang, Hui Li \\ Department of Finance and Economics, Wuhan City Vocational College, Wuhan, China \\ Email: 346969377@qq.com,15377015817@163.com
}

Received 7 April 2016; accepted 22 May 2016; published 25 May 2016

Copyright (C) 2016 by authors and Scientific Research Publishing Inc.

This work is licensed under the Creative Commons Attribution International License (CC BY).

http://creativecommons.org/licenses/by/4.0/

(c) (7) 0pen Access

\begin{abstract}
In order to realize the docking of students' professional quality training and enterprise occupation adaptability, we research on graduates' employment, professional quality and enterprises demand of a higher vocational college in Wuhan. Based on the data, we analyze existing problems of the students' professional quality training and occupation adaptability and put forward suggestions for further reform of the talent training scheme.
\end{abstract}

\section{Keywords}

Economic Management Major, Professional Quality, Occupation Adaptability

\section{Introduction}

In recent years, China's higher vocational education adheres to school policy which regards service as the tenet, employment as the guidance and the principle of industry-academy-research cooperation through exploration and practice such as opening vocational education resources, deepening the university-enterprise cooperation, constantly improving the breadth and depth of social services; higher vocational education is more and more close to law of education; features and advantages are gradually revealed (Wen, 2016). Data from the third survey organization we entrust show that in 2014, the vast majority of China's higher vocational college graduates employment rate is higher than that of the graduates from ordinary undergraduate colleges and universities. Although higher vocational graduate's employment rate and the average salary have risen in the past three years, there exist no difficult employment problems, but are qualified vocational graduates qualified professionals? Can they meet the requirements of enterprises? 


\section{Research Purpose and Method}

\subsection{The Research Purpose}

In order to deepen higher vocational specialty teaching reform of economic management majors, perfect the talent training plan, improve the quality of the students' employment, serve regional economic development to better realize the docking between students' vocational quality and enterprise demand, we should analyze the present situation of talent cultivation of professional quality and the present situation and problems of requirements (Sun \& Meng, 2011). According to statistics, employment rate of students majoring in economic management is higher than the average employment rate in recent two years, but the employment agreement and corresponding rate is not high. We conducted the research to solve these problems, the research is divided into two levels, one is focusing on graduate in order to understand their own professional quality evaluation and to know the real effect and the existing problems; the other is focusing on enterprises in order to know occupation group of graduates majoring in economic management and compare the students' professional quality evaluation with occupation requirements of enterprises to see whether there is a gap between them so as to gradually improve professional quality cultivation and adaptability of higher vocational students majoring in economic management (Li, Shao, \& Liu, 2010).

\subsection{The Research Object}

Our research is based on graduates from Department of Finance and Economics from two vocational colleges in Wuhan and enterprises which have close cooperation with colleges as well as part of enterprises of graduates in the last two years. We carry on research from 2014 to 2015.

\subsection{The Research Method}

Our research mainly adopts the method of questionnaire investigation, designed two questionnaires aiming at graduates and enterprise respectively, the questionnaire is divided into two parts. Student questionnaire contains student employment status, professional skills and self-evaluation of professional quality (Sun, 2008). Enterprise questionnaire includes talent demand situation and occupation requirement. The purpose of the questionnaire is to compare the students' professional quality with occupation requirements of enterprises and analyze occupation adaptability of cultivating the students' professional quality (Wang, 2007). The two questionnaires are attached as appendix. The students are from high vocational colleges and enterprises are small and medium-sized.

As for the graduates visit return, we hand out questionnaires to 200 students and actually get back 183, the recovery rate is $91.5 \%$. As for the enterprise survey, we hand out 80 questionnaires and actually get back 68 ; the recovery rate is $85 \%$. We analyzed the questionnaires by SPSS.

\section{The Results of the Survey and Analysis}

\subsection{Situation of Student's Employment and Enterprise Talent Demand}

In order to understand employment situation of graduates majoring in economic management from higher vocational colleges and professional talent demand situation of enterprises and to see whether there is balance between talent supply and demand (Xiang, 2010). We first research on student's employment occupation group and job satisfaction, at the same time; we also research on enterprise occupation setting and talent needs of enterprises.

According to the survey, students' employment has the highest percentage of jobs in financing, finance and marketing, but also involves the planning, human resources, warehouse, secretarial and administrative, production and other positions; the specific distribution is shown in Table 1 as follows.

Based on the survey of enterprises and Figure 1, we know that enterprises set up administration positions including financing, finance, human resources, marketing, planning, administration, warehouse and clerical positions, thus we can preliminary know that the graduates employment and economic management job setting of enterprise is consistent, as long as the enterprise set up post, there are graduates in related employment (Fu \& Sheng, 2010). In graduate employment type, private enterprises are in the majority, through the analysis, we know that higher vocational students are high-skilled talents, and fresh graduates who lack practical experience, relying on more smaller private enterprises, and this is also confirmed in enterprise survey, $80 \%$ of enterprise 
Table 1. Employment occupation of graduates majoring in economic management.

\begin{tabular}{cc}
\hline Occupation & Percentage \\
\hline Financing & $42 \%$ \\
Finance & $12 \%$ \\
Marketing & $18 \%$ \\
Planning & $4 \%$ \\
Human resources & $5 \%$ \\
Warehouse & $9 \%$ \\
Secretarial & $7 \%$ \\
Others & $3 \%$ \\
Summation & $100 \%$ \\
\hline
\end{tabular}

Occupation group of enterprises $\left\{\begin{array}{l}\text { Accounting } \\ \text { Financing } \\ \text { Human resources } \\ \text { Marketing } \\ \text { Planning } \\ \text { Public relation } \\ \text { Warehouse } \\ \text { warehouse }\end{array}\right.$

\section{Figure 1. Occupation groups of enterprises.}

surveyed are below 100 people, which also suggests that graduates employment are small and medium-sized enterprises.

In addition, job satisfaction of graduate show that only $43 \%$ of the graduates in employment show that they are very satisfied, and half of all graduates show their average satisfaction and even no satisfaction. As for talent demand survey of enterprise, $70 \%$ of the enterprises in the next three years demand talents of administration, $35 \%$ of which need more than 10 people, 22\% of which need between 5 - 10 people, $20 \%$ of which need less than 5 people, under the large base of small and medium-sized enterprises, the talent demand is still very strong. According to what has been said above, on the one hand, graduates haven't found a satisfactory job, on the other hand, talent demand of enterprises is far from satisfied.

Above all, school policy which is to cultivate applied talents for small and medium-sized enterprises is clear and the goal occupation group setting is consistent with market demand, but under such circumstance, talent training effect is not ideal enough, there is a certain gap between talent supply and demand of enterprise.

\subsection{The Ability Training of Students and Enterprise Occupation Requirements}

In order to understand the situation between student ability training and enterprise occupation requirement adaptability, we first classify ability of students, respectively, professional skills, social skills and learning ability (Jin \& Xing, 2012). Professional skills refer to the methods and means of employees in a specific job; Social ability is comprehensive ability in the process of work to understand society, adapt to the society and deal with problems; learning ability refers to ability in the process of work to update knowledge, adapt to environmental changes and meet the career development. Our questionnaire focuses on the above 3 abilities.

1) Professional adaptability

Professional skill is divided into professional skill and general skill, professional skills refers to special pro- 
cessing methods and professional judgment ability (Ding, 2013). Professional skill of each position is different, such as accounting treatment ability of accounting, marketing skills of sales, etc. It is not easy for enterprise to directly understand the candidate's professional skill levels in the recruitment process in short time, thus, they will consider professional qualification certificate, vocational skill competitions and work experience. We also survey students and enterprises. According to our survey, we know that almost all enterprises in selecting fresh graduates will give priority to graduates with professional qualification certificate, $85 \%$ of the enterprises need required qualifications, $35 \%$ of the enterprises required junior qualifications and $8 \%$ of enterprises required intermediate qualifications. According to the statistics of students, rate of qualifications is $81 \%$, rate of primary qualifications is $32 \%$, rate of intermediate and above qualifications is 0 . Therefore, we must strengthen the student's training to achieve a higher level of certification. As for skills competition, the enterprise also showed more attention to graduates who participated in the vocational skills competition, $85 \%$ of companies take a fancy to students in vocational skills competitions, the higher the level of competition and the higher recognition. Award rate of students at national skills contest was $3 \%$, provincial skills competition award rate was $10 \%$, school skills competition award rate was $30 \%$, however, still less students can directly benefit from competitions. As for survey of work experience, only $10 \%$ of enterprises has no request, $22 \%$ of enterprises require minimum 1 year work experience, $28 \%$ of enterprises require two-year work experience, as much as $40 \%$ of enterprises requires three years and above working experience, and our graduates at most have a few months of part-time and work experience, thus gap between students from the requirement of enterprises is bigger, but 1 - 3 years of working experience can also be interpreted as a disguised form to applicant ability of rapid job requirements, as a fresh graduates, though it is hard to have long work experience, but this rapid mount guard adaptability can be cultured in the learning process. Therefore, the school must focus on training students with corresponding occupation; make the graduates able to work at his position.

General skill is essential skill in the work but is not directly related to professional knowledge, such as computer operation skill, language and foreign language skill, etc. From general skills survey, enterprise demand for several indicators is balanced, $24 \%$ of students show their in-confidence in foreign language, $31 \%$ of students show their no interest in economic practical writing. In order to gain general ability, specialized courses are for students at colleges, but most students' application ability is weak in general skills. The above are shown as Table 2 and Table 3.

2) Social adaptability

Questionnaire subdivide social ability to eight indicators as communication ability, teamwork ability, decision analysis ability, executive ability, social cognition ability, compressive ability, time management skill, and

Table 2. Requirement for working experience.

\begin{tabular}{cc}
\hline Requirement & Percentage \\
\hline One year & $22 \%$ \\
Two years & $28 \%$ \\
Three years or more & $40 \%$ \\
No & $10 \%$ \\
Total & $100 \%$ \\
\hline
\end{tabular}

Table 3. Occupation qualification certificate.

\begin{tabular}{cc}
\hline Occupation qualification & Percentage \\
\hline Accounting qualification certificate & $39 \%$ \\
Securities qualification certificate & $38 \%$ \\
Assistant accountant certificate & $13 \%$ \\
Marketing qualification certificate & $10 \%$ \\
Total & $100 \%$ \\
\hline
\end{tabular}


vocational values (Huo \& Ren, 2014). These 8 variables are summarized by face-to-face interviews with people from enterprises we research on. Enterprises are required to choose the most important ability they focus, students are required to choose their ability, the results of the survey is shown in Figure 2. We can see from the diagram, the students' ability in all of the projects have gap with the requirements of the enterprise, of which the compressive ability, decision analysis ability, social cognitive ability and vocational values gap is more obvious.

3) Learning adaptability

Learning ability is subdivided into knowledge desire, Information acquisition ability; knowledge migration ability and logical thinking ability, as for learning ability, enterprises mainly take a fancy to candidate's learning attitude, namely, knowledge desire, followed by other abilities (Research Team, 2010). Students showed a higher confidence in the ability to learn, in order to adapt to the need of society after graduation, generally have modest learning attitudes and thirst for knowledge, and after school training, also have strong ability of selfstudy. So the learning ability of students and the needs of the enterprises showed better adaptability.

\section{The Problems and Suggestions}

With the rapid development of our economy, the changing of industrial structure and widely used of science and technology in the production, the social demand for applied talents majoring in economic management increases (Sun, 2013). In order to realize better and faster development of the Wuhan city circle, regional financial center in Wuhan must be built, which requires professional talent training of students majoring in economic management of higher vocational colleges must be linked to the regional economic development to meet the requirements of enterprise.

\subsection{Talent Training Scheme Should Be Further Improved Because There Exists Gap between Student's Cultivation and Enterprise Demand}

Based on positioning to cultivate applied talents with many skills for small and medium-sized enterprise, we should perfect the talent training scheme in details, course system should focus on promoting the development of a series of student ability; the teaching method should be reformed in the process of teaching to cultivate various ability of students; At the same time we should make students clear their own professional orientation, encourage students to start from the basic work to realize professional development.

\subsection{There Exists a Gap between Professional Skills and Job Requirements of the Students; We Should Improve Students' Professional Skills through Double Certificate Training, Skill Competitions, Training and Practice}

We should guide the students to do early career planning and focus on encouraging students to get higher vocational certificate; Provide students with a broader platform for the skills competition to exercise students and let more students have the opportunity to participate in; to strengthen the simulation training and practice, make students have the ability to quickly adapt to the job; Pay attention to the cultivation of the students' general ability and take computer application, language expression into consideration in professional teaching.

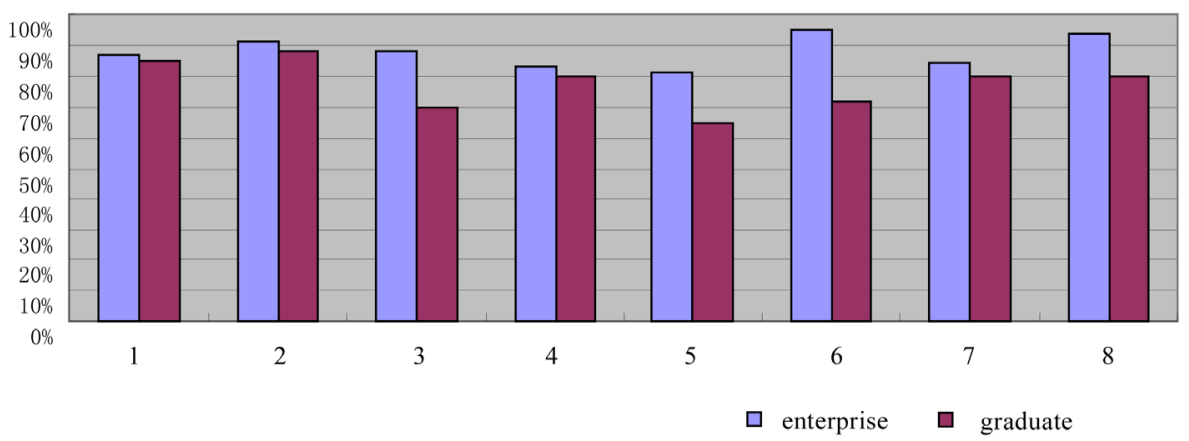

Figure 2. Comparison chart of the students' social ability and job requirements. 1: communication skills; 2: team spirits; 3: decision analysis skill; 4: executive skills; 5: social cognition skills; 6: work under pressure; 7: time management; 8: occupational values. 


\subsection{There Exists a Gap between Social Ability and Job Requirements of the Students, We Should Promote Students' Comprehensive Ability and Strengthen Students' Psychological Health Education}

Comprehensive ability cannot rely on specialized courses and it should be focused on through the talent training, such as to cultivate the students' decision-making ability, analysis ability in specialty courses; to cultivate the students' team spirit, work timeliness in the practice; to cultivate the students' ability of compression in the professional competition and professional certificates; to cultivate the students' ability of social cognition in the club activities, etc., in short, social ability should be decomposed and integrated into the curriculum system.

\subsection{A Reasonable Evaluation System of Skilled Talents Should Be Built}

The construction of high-skilled talent team of long-term planning (2010-2020), pointed out that we should gradually establish evaluation system of high-skilled talents which regards professional ability as the guidance, focus on the work performance, professional ethics and professional knowledge, which means that the core content of evaluation of skilled talents of higher vocational colleges consist in moral, intellectual, ability and performance.

Combing cultivation object of higher vocational colleges, four-element-structure model of performance evaluation of high-skilled talents training in higher vocational colleges should be constructed from quality, knowledge, skill and performance.

\subsection{Learning Ability of Students Should Be Strengthened}

Finally, students' learning ability should be strengthened in order to make the students who graduate have selfstudy ability and self-improvement ability, which will enable students to gain a better career development and lifelong benefit.

\section{Funding}

This work is supported by "Teaching Research Project of Wuhan Municipal College” in 2011: Abutment Studies between Vocational Skills Training and Enterprise Post Demand of Accounting Major of Higher Vocational college [grant No.2011032].

\section{References}

Ding, J.-C. (2013). The Situation Analysis and Route Choice of Higher Vocational Education Docking to the Regional Economy. Journal of Higher Education, 3, 61-66.

Fu, Y. Z., \& Sheng, F. Q. (2010). Research on the Situation, Problems and Measures of Hubei Universities Serving Economic and Social Development. Hubei Social Sciences, 6, 71-73.

Huo, R. G., \& Ren, L. J. (2014). The Situation Analysis and Route Choice of Higher Vocational Education in Hebei Province. Journal of Taiyuan Urban Vocational College, 12, 3-4.

Jin, L. J., \& Xing, H. X. (2012). Paths of Higher Vocational Education Serving Regional Economy. Modern Enterprise Education, 7, 44-45.

Li, Y.-J., Shao, Q., \& Liu, H. Y. (2010). Lack of Employment Ability of College Students Majoring in Economic Administration from Industry Colleges and Countermeasures. Journal of Education Research, 4, 11-14.

Research Team (2010). Status of Higher Vocational Education in Six Provinces in the Middle of China and the Development Countermeasures. Vocational and Technical Education, 28, 33-37.

Sun, X. Z. (2013). The Research on the Paths and Forms of Local Universities Serving the Regional Economic Social Development. M.E. Thesis, China: Henan Normal University.

Sun, Z. S., \& Meng, H. (2011). Computer Professionals Demand Research Report. Computer Education, 10, 25-29.

Sun, Z. X. (2008). Research on Social Adaptability Training of Students from Vocational Colleges. Dissertation, University of Geosciences in China.

Wang, X. J. (2007). Research on Quality Training of Students of Higher Vocational Colleges. Journal of State Forestry Administration Management Cadre Institute, 1, 33.

Wen, N. (2016). Exploration and Practice on the Training of the Professional Quality of High Skilled Talents in Railway. Journal of Higher Education, 5, 16-19.

Xiang, X. (2010). Research on Professional Quality Cultivation. Information Technology, 5, 22-24. 


\section{Appendix}

\section{Questionnaire on Demand of Graduates Majoring in Business Administration from Higher Vocational Colleges (for Enterprises)}

Dear sir or madam,

In order to understand the current business situation and the demand for higher vocational management professional talents ability and quality requirements, to provide the necessary support for our major, education and teaching reform, we set up this questionnaire, hope to hear your valuable advice. The questionnaire is only for research, no other business purposes. We ensure that all the information about the companies is not outflow.

Thank you for your interest in the higher vocational education teaching reform and talent training to provide support and help!

Department of Finance and Economics, Wuhan City Vocational College.

\section{Part 1. Basic information of your company}

The full name:

Address:

Contact tells:

E-Mail:

1) Nature of your company: (note: $\sqrt{ }$ )

State-owned enterprise ( ) Private enterprise ( )

Joint venture enterprise ( ) Sole proprietorship enterprise ( ) others:

2) Business areas:

Industrial enterprise ( ) Business enterprise ( )

Financial enterprise ( ) Service enterprise ( ) other:

3) Number of employees:

Under 20 people ( ) 20 to 50 people ( )

50 - 100 people ( ) more than 100 people ( )

4) Foundation time:

Within five years ( ) 5 - 10 years ( ) more than ten years ( )

Part 2. Talent demand information investigation (you can choose more, if you choose other items, please indicate on the horizontal line)

5) Staff structure at present:

The total number of employees is ( ), including:

A. people with master degree ( ) B. undergraduate ( ) C. college (vocational) ( )

D. secondary (high school) people ( ) E. people below high school ( )

6) What are related jobs? ( )

A. financial B. human resources C. marketing D. other jobs

7) Your demand for professional talents of business administration over the next three years ( )

A. there is demand, less than 5 people $\quad$ B. there is demand, 5 - 10 people

C. there is demand, more than 10 people D. no demand E. uncertainty

8) The way you introduce talents (three alternatives) ( )

A. recruit graduates from colleges and universities B. talent market intermediary

C. introduce non-local talents D. acquaintances recommended E. cyber recruiting F. other

9) For recruitment, degree requirements for talents: ( )

A. Technical secondary school degree B. college degree

C. bachelor degree $\mathrm{D}$. graduate degrees

10) For recruitment: (requirement of talents' physical condition in three alternatives) ( )

A. gender B. height C. physical situation D. manners E. other

11) For recruitment :( requirements of talents' psychological quality in three alternatives) ( )

A. compressive capacity B. emotional control ability C. character qualities D. other

12) For recruitment, the requirement to the learned professing: ( )

A. strict professing B. same major categories C. your major is not strictly required

13) For recruitment, the demand of grades for fresh graduates: ( )

A. No request B. medium C. above the top D. Other 
14) What ability you care most: ( )

A. cooperation ability B. communication C. thinking ability D. learning ability E. other

15) Which professional consciousness you care most: ( )

A. professional ethics spirit B. Professional dedication C. desire D. learning spirit E. other

16) Your requirements for talent work experience: ( )

A. no request B. one year C. two years D. more than three years E. other

17) For recruitment management talent, your requirement of the qualification certificate: ( )

A. accounting practitioner's qualification certificate B. securities from job seniority certificate C. assistant accountant certificate D. marketing qualification certificate

E. other

18) What aspects you care most: (choose four items in turn) ( )

A. degree B. physical and mental quality C. general ability D. professional ability

E. work and social experience $\mathrm{F}$ professional consciousness

19) What do you think the main difficulties faced by graduate for their job searching: choose four items in turn) ( )

A. lack of working experience B. no solid basis of knowledge of professional C. lack of mental suffering D. hands-on ability is poor E. poor interpersonal skills F written expression ability is poor G. other

20) Whether your company is willing to cooperate with us for the following items? (note: $\sqrt{ }$ )

( ) Appoint professionals to us for part-time teaching

( ) Appoint professionals to us to guide teaching

( ) accept our students to your company for field work

( ) takes teachers to your company for project cooperation

21) What your requirements for talents training related to business management?

\section{Questionnaire on Employment and Professional Quality Status of Higher Vocational Students Majoring in Accounting}

Dear students:

To further do a good job of higher vocational education, make the talents training goal of higher vocational accounting more accord with the demand of the professional post, facilitate understanding higher vocational accounting professional knowledge structure and ability quality, understand accounting major graduates employment situation, meet the demand of the position, for our professional education and teaching reform research to provide the necessary support, we make this questionnaire, hope to hear your valuable advice. The questionnaire is only for research, no other business purposes; we ensure that all information is not outflow.

Thanks to your support and help!

Department of Finance and Economics, Wuhan City Vocational College.

1) Your gender? A. male B. female

2) What do you graduate? A. 2012 B. 2013 C. 2014

3) What is your current employment status?

A. employment B. entrance C. self-employment

D. underemployed E. temporarily underemployed

4) What do you think of your company?

A. very satisfied B. satisfied C. general D. not so satisfied

5) You have office or employment intention of the future tendency of professional category is?

A. state-owned enterprises B. foreign-capital enterprise

C. certified public accountants D. civil servants

E. college F. private enterprise G. others

6) What is your job?

A. accounting B. cashier C. warehouse D. cashier E. sales F. secretarial

G. Other:

7) Why do you choose accounting?

A. personal interest B. social demand is great and the employment prospect is good

C. affected by others D. the importance of accounting in social work E. other reasons 
8) What do you think of teaching environment of accounting?

A. Fine B. good C. general D. very poor

9) What do you think of school teaching arrangement?

A. too tight B. moderate C. too loose, nothing to do

10) How do you evaluate the quality of the accounting teaching?

A. very satisfied B. satisfied c. b. not satisfied

11) What do you think the position of accounting in the department of economic management activities?

A. quite important B. very important C. important D. not important

12) Do you think your knowledge can afford an accounting job?

A. basically could B. completely could C. Should be able to D. cannot afford

13) What do you think of overall level and quality of accounting personnel in our country?

A. generally high $\mathrm{B}$. higher C. relatively low

14) What professional quality should you have? (multiple choice)

A. professional ethics quality B. professional judgment ability C. physical and psychology comprehensive quality D. professional knowledge E. creative thinking F. interpersonal ability

G. foreign language communication ability H. personal work attitude I. organizational leadership ability J. team coordination ability K. broad business perspective l Other

15) What factors do you think company cares most? (multiple choice)

A. the diploma degree B. good study C. rich experience in student work

D. rich internship E. honors F. good working ability

G. hard work spirit H. innovation ability I. other

16) Comparing with professional ability and quality requirements of the employment, what do you think of your current professional quality?

A. very close, high alignment

B. there is differences, but also can adapt to work the basic requirements

C. difference is very big, and the social demand for professional quality is of derailment

17) What do you think the practical skills should be engaged in accounting work? (multiple choice)

A. the abacus B. cashier skills C. risk analysis D. foreign language level

E. financial software application F. office software application G. accounting manual check

H. writing I. bank business J. other

18) When you encounter problems, how do you handle and solve?

A. take it step by step B. face it, actively looking for ways to solve

C. seek new ways to solve and innovation method by one-self D. consult others and cooperation

19) What professional quality do you think an accounting professional need to have most?

A. practice experience B. professional skill C. theory knowledge D. moral quality

20) What do you think is the most important in accounting professional ethics education?

A. ideological education B. legal education C. moral education

D. psychological quality education E. warning education

21) What related certificates should you get in school? (multiple choice)

A. financial qualification certificate B. certificate of English C. computer certificate

D. securities qualification certificate E. other

22) Do you have intention to enter an examination, such as certified public accountants, certified?

A. yes, clear B. haven't decided yet C. no consideration

23) What do you think should be added in the professional curriculum? (multiple choice)

A. professional ethics and integrity education B. career planning education

C. skills and comprehensive practical simulation education D. entrepreneurial skills training

E. document writing ability training F other:

24) How do you think of this professional employment prospect?

A. very optimistic, talents shortage B. general

C. not optimistic, employment pressure D. impossible to judge

25) What professional quality do you think you now need to strengthen? 